\title{
Using Chloroquine and Hydroxychloroquine in the Treatment of COVID-19: Does It Make Sense?
}

\author{
Ronan Batista \\ Department of Organic Chemistry, Chemistry Institute, Federal University of Bahia, Salvador, Bahia, BRAZIL.
}

\begin{abstract}
The severe acute respiratory syndrome caused by the new coronavirus SARS-Cov-2 (COVID-19) has quickly turned into a pandemic, infecting more than 10 million people and causing more than 500,000 deaths worldwide. The absence of an effective treatment against this disease has led several researchers to investigate the possibility of redirecting drugs already known to be effective against other diseases in the treatment of COVID-19, among them the antimalarial drugs chloroquine and hydroxychloroquine. This review aims at showing how chloroquine and hydroxychloroquine came to be considered as possible drugs in the treatment of COVID-19 and how the recent in vivo experiments described so far shed light on the adequacy of this use.
\end{abstract}

Key words: COVID-19, SARS-Cov-2, Coronavirus, Chloroquine, Hydroxychloroquine, antiviral activity.

\section{INTRODUCTION}

"Using chloroquine and hydroxychloroquine in the treatment of COVID-19: does it make sense?" This question has arisen in recent months in view of the vast discussion witnessed in the media about the possible use of these drugs in the treatment of COVID-19. Really, at first, it seems quite uncommon because both chloroquine (CQ) and hydroxychloroquine (HCQ) are classically antimalarial drugs that have also been repositioned in the pharmaceutical market for the treatment of some autoimmune diseases, such as lupus and rheumatoid arthritis, among others. But, after all, why would CQ or HCQ, both antimalarial drugs, make sense in the treatment of an infectious disease caused by the new coronavirus? This issue was the driving force behind the gathering of data on this subject and the writing of this article. A combined systematic and narrative review on articles published until June 2020 reporting antiviral properties of both CQ and HCQ was carried out to bring more relevant and accessible technical information to a larger portion of society, thus contributing to enrich their understanding and better base their opinion on this subject.

This paper is organized in three main parts. The first one will address basic information about SARS-Cov-2, highlighting the onset of the disease, the viral structure and the stages of infection of this new coronavirus. A second step will take a brief historical approach to the emergence of CQ and HCQ and will comment on their antiviral and anti-inflammatory properties. Finally, the third part will comment on the results of the latest in vivo experiments with these substances against COVID-19 and discuss whether there is, in fact, any safe relationship between these molecules and their possible use in the treatment of this disease.

\section{SEVERE ACUTE RESPIRATORY SYNDROME (COVID-19)}

The term "COVID-19" represents the abbreviation of the English expression "Corona Virus Disease" and the number "19" of that term indicates the year in which the first report of this disease was made in
Submission Date: 08-07-2020; Revision Date: 08-09-2020; Accepted Date: 07-10-2020

DOI: 10.5530/ijper.54.4.179 Correspondence: Dr. Ronan Batista Department of Organic Chemistry, Chemistry Institute, Federal University of Bahia, Rua Barão de Jeremoabo, s/n, Ondina, 40170-115 Salvador, Bahia BRAZIL.

Phone no: 55-71-32836841 Email id: ronbatis@ufba.br

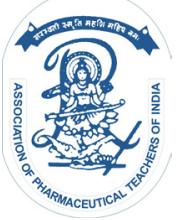

www.ijper.org 
the world (2019). On December 31, 2019, the World Health Organization's office in China received a statement that the first reports of an unknown pneumonia had arisen in Wuhan city, Hubei province, China. ${ }^{1}$ A week later, Chinese authorities reported the discovery of the causative agent for this new type of pneumonia: a new coronavirus (Figure 1), which was named SARS-Cov-2, an English expression meaning Severe Acute Respiratory Syndrome Coronavirus-2. ${ }^{2}$ This epidemic quickly turned into a pandemic, being recorded in just a few months in practically all 216 existing countries and surpassing the mark of 10 million infected and 500 thousand deaths worldwide. ${ }^{3}$

This new coronavirus belongs to the Coronaviridae family, which is subdivided into four genera based on their genetic properties: Alphacoronavirus, Betacoronavirus, Gammacoronavirus and Deltacoronavirus. Coronaviruses can infect not only humans but also many species of animals, such as dogs, cats, rodents, cattle, pigs, horses, camels, birds, bats, rabbits and other wild animals. SARS-Cov-2, which causes the current pandemic, together with the species SARS-CoV and MERS-CoV (coronavirus that causes respiratory syndrome in the Middle East) which were responsible for recent epidemics that occurred in 2002-2003 and 2012, respectively, all belong to the Betacoronavirus genus and are zoonotic pathogens that can cause more severe respiratory diseases in humans. Besides them, the species HKU1, NL63, OC43 and 229E also infect humans, but cause milder symptoms. ${ }^{2}$

Figure 1-A shows a photo of the SARS-CoV-2 coronavirus by electron microscope. This group of viruses is characterized by a crown appearance, hence the term "corona" in the name. Figure 1-B shows, schematically, the main parts that constitute the viral structure of the coronavirus, namely: the "S" glycoprotein, also known as "Spike protein", represented in yellow; the membrane protein $(\mathrm{M})$, the main component of the envelope $(\mathrm{E})$, both represented by the brown structure; and finally the RNA genome, single and positive strand, wrapped in the "N" protein, thus forming a nucleocapsid that is represented by the structure in green.

The process of infection and replication of the coronavirus occurs in the epithelial cells of the human respiratory tract and is schematically represented in Figure 2. The lungs are the organs most compromised by COVID-19 because the coronavirus readily recognizes the cells of these organs due to the high affinity that the Spike protein has by the receptor of the angiotensinconverting enzyme 2 (ACE-2), more abundant in the membrane of the alveolar cells of the lungs. The

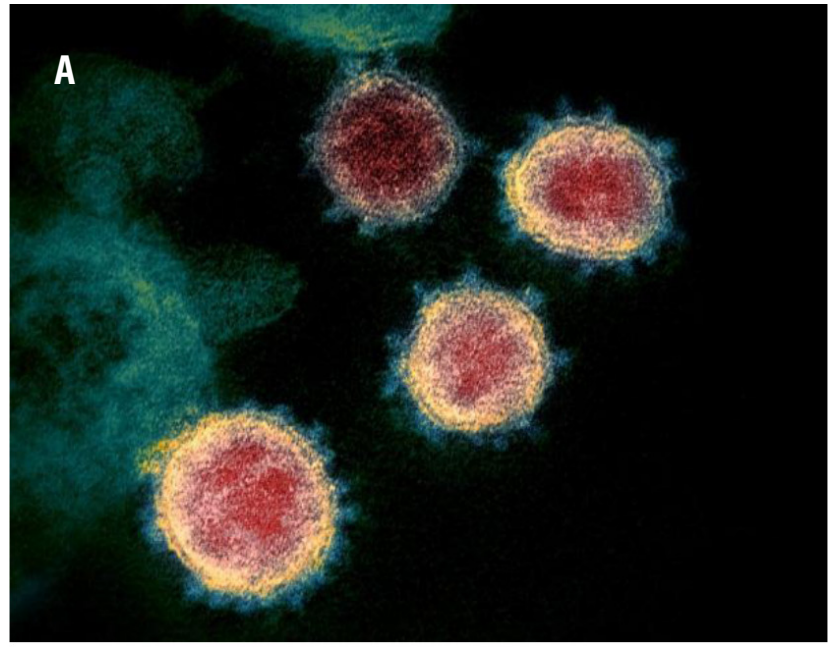

B

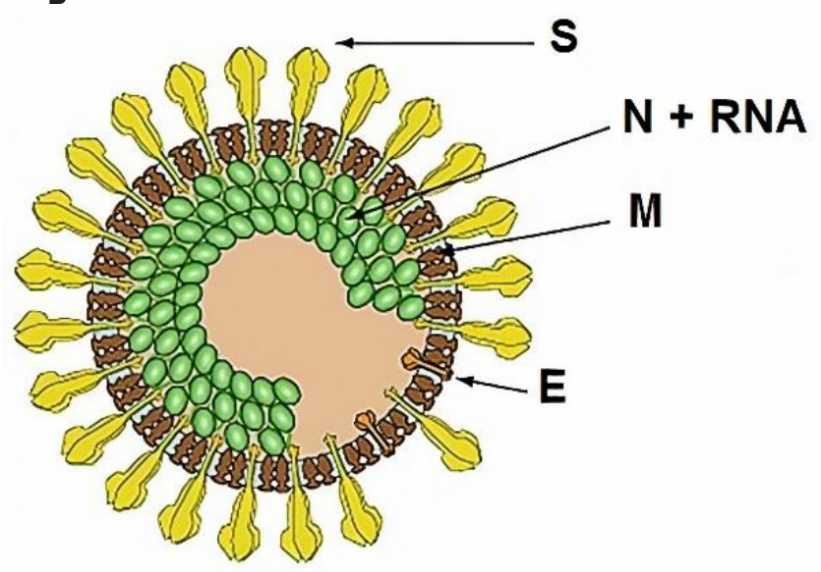

Figure 1: Images of the new SARS-CoV-2 coronavirus. A). Microphotography by electron microscope in enhanced colours. Thorn-shaped protein, known as "S protein" or "Spike protein", can be seen in the blue color surrounding the particles with red nucleus and yellow border (Photo: National Institute of Allergy and Infectious Diseases); ${ }^{4}$ B). Schematic representation of the main parts that constitute the coronavirus' structure: S, Spike protein; N + RNA, protein $\mathrm{N}$ and RNA genome; $\mathrm{M}$, membrane protein; $\mathrm{E}$, envelope (Image adapted from ViralZone). ${ }^{5}$

adsorption step, therefore, represents the binding of the virion to the membrane surface of the host cell (Figure 2, Step 1). Through endocytosis, the endosomes are then formed (Figure 2, Step 2) and then become lysosomes (Figure 2, Step 3). The acidic $\mathrm{pH}$ of the lysosome allows the envelope of the virus to join the membrane of this organelle, launching the genomic material out of the lysosome. Next, since it is released into the cytoplasm (Figure 2, Step 4), the genomic RNA will follow both the path of transcription - formation of new RNA genetic materials and translation along the ribosome to form the enzymes and proteins that will make part of the future virus structure which will be formed (Figure 2, Step 5). Finally, in the assembly 


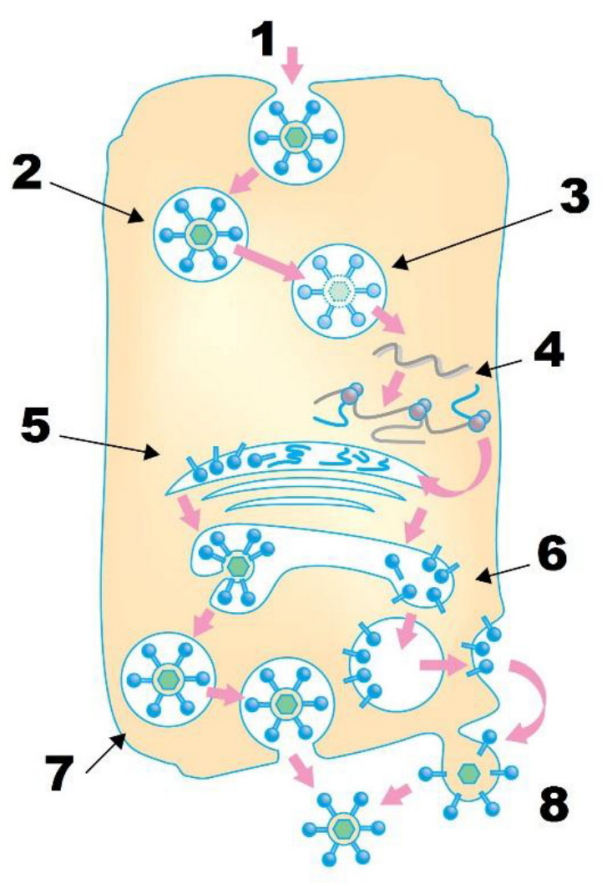

Figure 2: Stages of coronavirus infection and replication in human lung cells. 1. Adsorption and invasion by endocytosis; 2. Transport of the virus through the endosome; 3. Endosome evolves into lysosome and then the virus loses its envelope and releases its genome in the cell cytoplasm; 4. Replication and transcription of the viral genome; 5. Post-translational processing of envelope glycoproteins in the Golgi complex; 6. Transport of the components of the envelope; 7. Transport of newly formed viral units; 8 . Release of the virus to the outside of the cell. (Image adapted from The Lancet). ${ }^{8}$

phase, the material is collected in the form of a nucleocapsid which, upon entering the Golgi complex, then forms the final structure of the virus (Figure 2, Step 6), which will then be released to the outside of the cell via of a Golgi vesicle (Figure 2, Steps 7 and 8). These new viruses will then infect other cells and the cycle begins again. ${ }^{6,7}$

\section{HOW DID CHLOROQUINE AND HYDROXYCHLOROQUINE ARISE IN THE PANDEMIC CONTEXT?}

In order to understand how CQ and its derivative HCQ emerged in this context of the COVID-19 pandemic, we should first refer to the beginning of our history in order to understand when and how the first antimalarial emerged since the discovery of the Americas.

The tree known as "Quina-Quina" and "Cinchona", popular names given to Cinchona species (Rubiaceae), was discovered in the late $16^{\text {th }}$ and early $17^{\text {th }}$ centuries during the period of conquest of the Inca Empire by the Spanish in South America. Legend says that, during the reign of the Count of Cinchón as viceroy of Peru between 1628 and 1629, the viceroy's wife, the Countess of Cinchón, was stricken with malaria in Lima. Because she was a very popular person, news of her illness quickly spread to all the people in the country side and finally reached the Lloxa region, where a Spaniard was in the government. He promptly sent the sick Countess a medicine obtained from the bark of a tree found in that region. Days later, the therapeutic result obtained was extraordinary: The Countess of Cinchón improved quickly and, therefore, because she was so delighted with the result, she distributed this remedy to the poor people of Lima who also suffered from tertiary fevers. It is believed that, based on this tale, the Swedish botanist Carl Linnaeus (1707-1778) would have named the tree as "Cinchona" in honour of the Countess of Cinchón. The discovery of QuinaQuina was a remarkable scientific fact in medicine at the time, because many people began to be cured of malaria using the powder from Quina-Quina bark, which in the subsequent years led to a rapid export of seeds from that plant to other parts of the world, mainly Europe and Asia. ${ }^{9}$

However, another memorable scientific breakthrough took on an even greater role in history almost 200 years later. In 1820, the French chemists Pierre Pelletier and Joseph Caventou described the isolation of quinine from the bark of Cinchona sp. and classified this substance as an alkaloid. Scientifically, this fact would definitely mark the history of Science because it started to have a pure substance (quinine) that would be used for the first time as an antimalarial drug. This allowed that adequate and standardized doses of this antimalarial could be administered in relatively smaller amounts compared to the amount of bark's powder used to achieve the same therapeutic effect. Subsequent studies on quinine showed that it, in fact, it inhibited the growth of Plasmodium falciparum, the causative agent of malaria, only in the acute phase of the disease. However, quinine was not as efficient in the chronic phase as it was unable to stop the sporulation of schizonts and gametocyte development. ${ }^{10}$

Later, during the First World War (1914-1918), it was observed that many armies were immobilized on the Balkan peninsula because of malaria, resulting in the loss of the lives of many soldiers. At that time, it was said that malaria killed more soldiers than the enemy artillery itself. Even so, many lives were saved in the British and French armies thanks to the use of quinine. ${ }^{11}$ In addition to their valuable medicinal use, antimalarial drugs also began to assume military and strategic importance, which stimulated many researches that followed in the post-war period in the search for new 


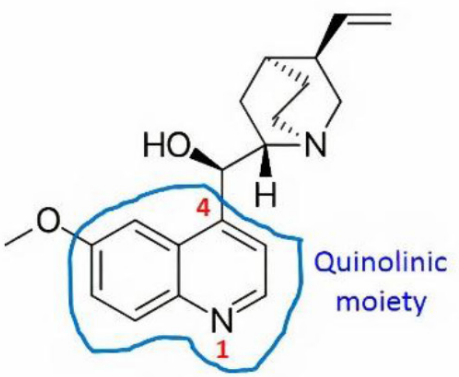

QN

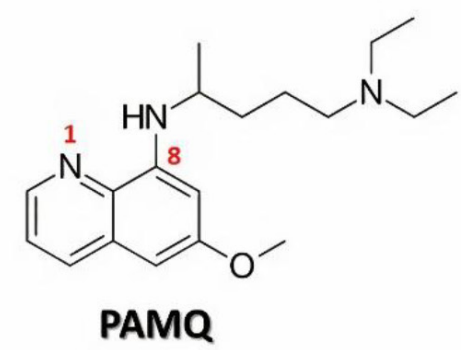

1926

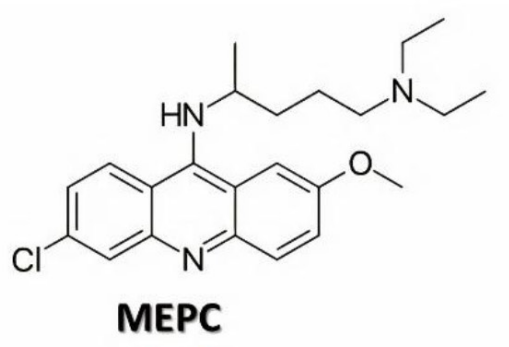

1932

Caventou \& Pelletier, 1820

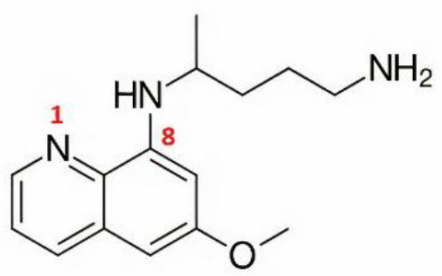

PRIMQ

1946

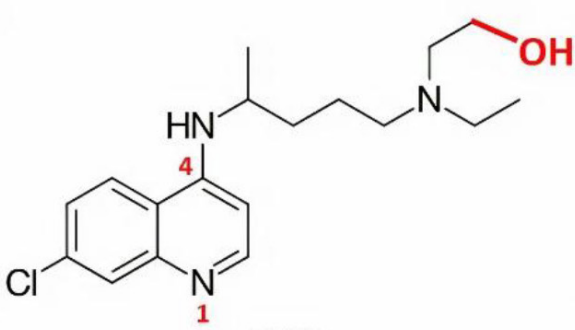

HCQ Surrey \& Hammer, 1946

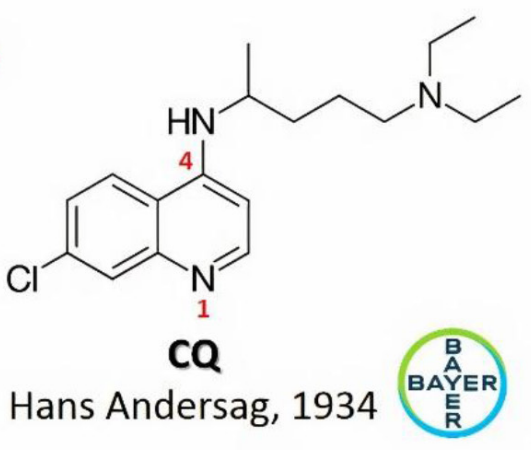

Figure 3: Molecular formulas of quinine and the first synthesized quinolinic antimalarials.

antimalarial drugs inspired by the quinine's structure (Figure 3, QN). Pamaquine (Figure 3, PAMQ), discovered in 1926, also known as plasmoquine, was the first synthetic antimalarial with an 8-aminoquinoline nucleus that later inspired primaquine synthesis in 1946 (Figure 3, PRIMQ). Mepacrine (Figure 3, MEPC), an acridine, was synthesized in 1932 and only then, in 1934, the preparation of 4-aminoquinoline chloroquine (Figure 3, CQ) was announced by Hans Andersag in Bayer laboratories. ${ }^{9}$

Initially, Bayer rejected CQ since this compound appeared to be toxic to human use. ${ }^{12}$ In May 1945, however, after being tested in many naturally infected patients, the CQ showed an efficient antiparasitic action with a rapid decrease in the symptoms of malaria, accompanied by a relatively low toxicity as evaluated by the American researchers who conducted the study. Thus, from the beginning of the 1950s, CQ started to be recommended as the medicine of choice for the treatment of all cases of malaria in the world. ${ }^{13}$ The purpose of replacing quinine with new antimalarial substances, such as CQ, in order to increase the number of drugs available on the market for the treatment of this parasitic disease, also led to the first synthesis of hydroxychloroquine (Figure 3, HCQ) described by the researchers Surrey and Hammer, in 1946, at SterlingWinthrop Research Institute in New York, United States. ${ }^{14}$ They expected that the introduction of a hydroxyl in the primary carbon of one of the $N$-ethyl groups would bring greater water solubility and less toxicity to the molecule. In fact, HCQ was proved to be less toxic to animals than CQ itself. ${ }^{15}$ Only in 1955, HCQ was made available as a medicine after receiving approval from the Food and Drug Administration (FDA). In 1953, the physician J. Charles Shee reported an accidental discovery: the daily administration of CQ sulfate to a 62-year-old patient resulted in the cure of her advanced chronic lupus erythematosus. ${ }^{16}$ This achievement opened the door for the use of CQ and HCQ in the treatment of autoimmune diseases such as lupus and rheumatoid arthritis, among others. ${ }^{17}$

\section{WHAT IS THE RELATIONSHIP OF BOTH CQ AND HCQ WITH ANTIVIRAL ACTION?}

In the early 1960s, several studies in different in vitro systems showed that, after the adhesion of viruses to the surface of the cytoplasmic membrane of animal cells, viruses entered the cytoplasm through structures called "pinocytic vesicles" or "phagosomes". They observed that, inside these phagosomes which then turned into lysosomes, when exposed to the acidic $\mathrm{pH}$ and lysosomal enzymes of the host cell, the viruses use this hostile environment to lose their envelope next to the lysosomal membrane and release their genomic material into the cell cytoplasm. Therefore, substances that influence the 
stability of the lysosome membrane could also affect the virus's multiplication process within the host cell. ${ }^{18}$ Based on this hypothesis and in view of the observation made by Weissmann ${ }^{19}$ that CQ stabilizes lysosomal membranes under certain study conditions, Mallucci $(1966)^{18}$ investigated the in vitro effect of CQ on the growth of rat hepatitis coronavirus (MHV-3) in macrophage culture. His results showed that the exposure of these macrophages to increasing concentrations of CQ caused an increasing inhibition in the growth of the virus, until the complete disappearance of the virus at the highest concentration of CQ tested $(60 \mu \mathrm{g} / \mathrm{mL})$.

These results impelled the investigation of the antiviral action of these quinolinic antimalarials in other known viruses. It didn't take long for new results from in vitro experiments to show that CQ and/or HCQ also inhibited the growth of several other viruses that are pathogenic to humans and animals. Table 1 displays twenty virus species belonging to eleven families as being susceptible to the antiviral action of CQ and/ or HCQ in in vitro assays by means of different cell systems. Against SARS-Cov-2, it is curious to note that CQ was slightly more potent $\left(\mathrm{EC}_{50}=2.7-7.4 \mu \mathrm{M}\right)$ than HCQ $\left(\mathrm{EC}_{50}=4.5-13 \mu \mathrm{M}\right)$, although HCQ figures as less toxic than CQ.

In most of the studies listed in Table 1, the main mechanism of antiviral action of CQ and HCQ is attributed to the stabilization that these substances bring to lysosomal membranes due to the increase of $\mathrm{pH}$ within these organelles, thus causing interference in the loss of the virus envelope, which prevents the release of viral genomic material towards the cytoplasm of the host cell and thus interrupts its multiplication. Both CQ and HCQ are weak bases and, therefore, they are able to affect acidic vesicles and cause the dysfunction of several enzymes with the neutralization of this acidic $\mathrm{pH}$. Outside the cell, CQ and HCQ are largely in protonated form and become unable to cross the plasma membrane due to their positive charge. However, non-protonated molecules can enter the intracellular compartment and become immediately protonated by the very acidic $\mathrm{pH}$. Thus, these acidic organelles (endosomes, Golgi vesicles and lysosomes) accumulate more and more protonated CQ or HCQ, increasing their internal $\mathrm{pH}$. In this way, both CQ and HCQ can inhibit virus replication by interfering with its endosome and lysosome-mediated entry (Figure 2, steps 2 and 3), or in the final stages of virus replication (Figure 2, steps 5-7) that happen with the participation of Golgi vesicles. ${ }^{8,20}$

Recently, structural and molecular modelling studies have revealed a new possible mechanism of action for CQ and HCQ against SARS-Cov-2 infection. Considering that the first stage of the viral replication cycle is the adhesion of the coronavirus to the surface of the respiratory cells through the affinity of the viral protein Spike (Protein S) to the angiotensin-2-converting enzyme (ACE-2) receptor, in silico studies have shown that both CQ and HCQ bind to sialic acids and gangliosides with high affinity, making the viral $\mathrm{S}$ protein no longer able to bind to the cell surface gangliosides. Thus, according to these results, CQ and HCQ would act against the infection of this new coronavirus by disrupting the adhesion of this virus to the cell surface, preventing its subsequent entry into the cell's cytoplasm. ${ }^{38}$

Finally, it is worth remembering that CQ and HCQ also act on the human immune system. The accumulation of CQ and HCQ in lymphocytes and macrophages is responsible for the anti-inflammatory properties of these drugs, a fact that justifies them in the treatment of some autoimmune diseases such as rheumatoid arthritis, lupus erythematous and sarcoidosis, among others. All of these diseases show some relationship with the production of pro-inflammatory cytokines, such as tumor necrosis factor (TNF $\alpha$ ). Both CQ and HCQ reduce the secretion of such cytokines, especially $\mathrm{TNF} \alpha$, which causes a decrease in the body's inflammatory response. The mechanisms of TNF $\alpha$ inhibition by CQ and HCQ, together with other more detailed information on the anti-inflammatory action of these molecules, can be found in the extensive literature available ${ }^{17}$. The anti-inflammatory action may be an interesting side effect for repositioning molecules as antiviral drugs, since many viral infections are accompanied by inflammatory conditions, as it is the case of COVID-19.

\section{ARE CQ AND HCQ SUITABLE FOR USE IN THE TREATMENT OF COVID-19?}

In vitro (in Latin, "in glass") assays are experiments where biological processes take place outside living systems, in properly controlled, closed environments and usually performed in glass containers. In turn, in vivo tests (in Latin, "within the living") refer to experiments that occur or take place within a living organism.

Based on the results of in vitro tests that demonstrated the inhibitory action of CQ and HCQ against infection with the new coronavirus SARS-Cov-2 (Table 1), it is natural to expect that these antimalarials would also be active in in vivo experiments. In other words, if these molecules were active against SARS-Cov-2 in assays outside the body, they are also likely to fight this coronavirus inside the human body when administered to sick patients. 


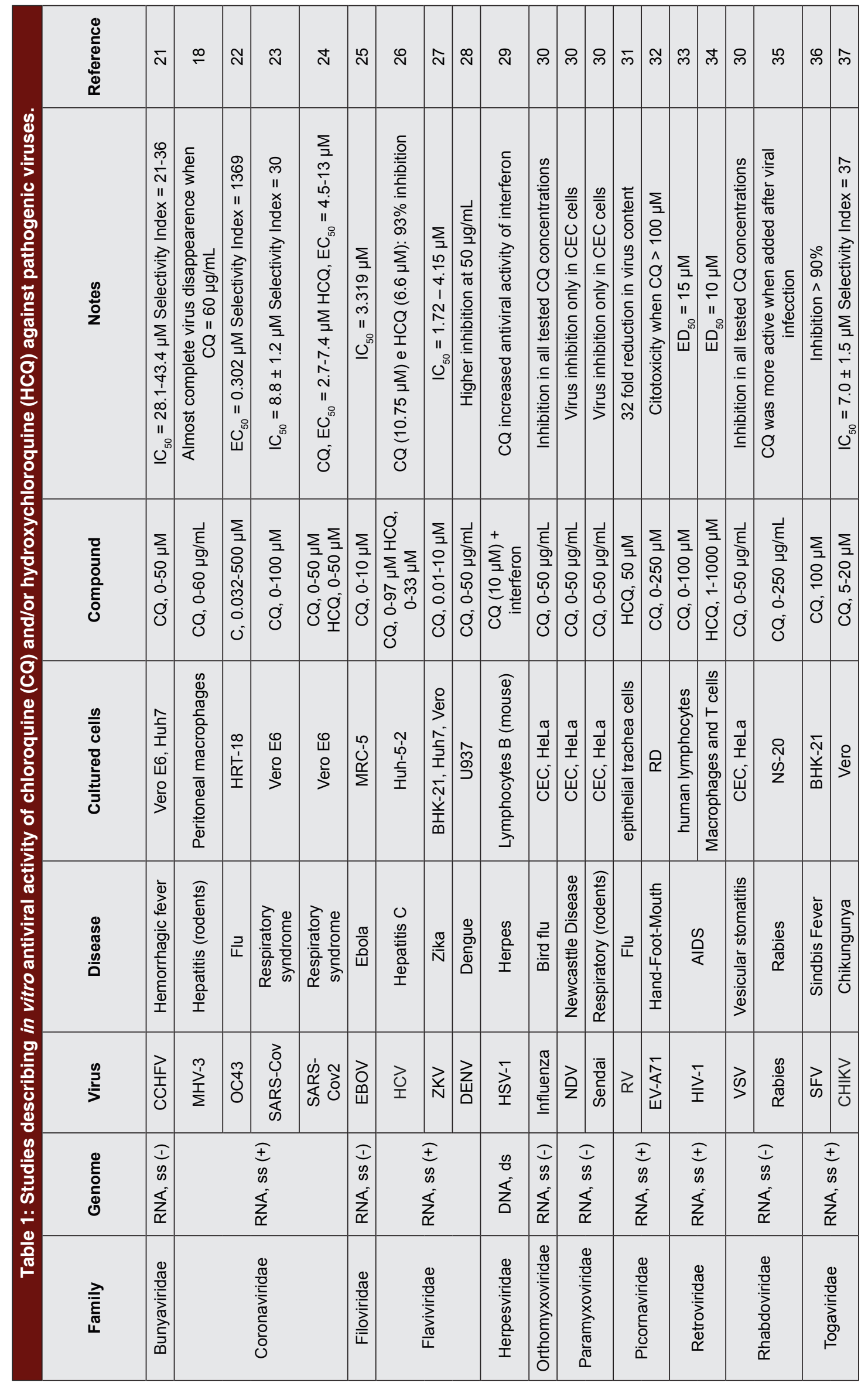


However, it is worth remembering that the premise that an in vitro active substance is also active in in vivo tests is not always confirmed in practice. ${ }^{39}$ The dose, route of administration, absorption, distribution and/ or bioavailability of the drug in the animal or human organism, among several other factors, may not guarantee that this substance effectively reaches its pharmaceutical target. $^{40,41} \mathrm{~A}$ clear example was shown in the study by Dowall and colleagues: $:^{25}$ although CQ has been shown to be active against the EBOV virus (Ebola) in in vitro tests (Table 1), it was harmless in experiments carried out on animals infected with this virus. The same happened against the Influenza virus (Table 1), where the antiviral action of CQ first appeared in in vitro assays, but later in vivo experiments demonstrated that $\mathrm{CQ}$ was not effective in preventing influenza infection in a clinical study in humans. ${ }^{42}$ Therefore, these and countless other examples easily found in the literature guide us in the sense that there is an evident and imperative need to confirm the in vivo antiviral action of CQ and HCQ before these drugs are officially available for the treatment of COVID-19. The choice of not following this protocol can result in an ineffective treatment of the disease associated with a risk of unnecessary exposure of the patient to various side effects and serious adverse effects that these drugs bring with them. With the use of CQ / HCQ, there are real risks of blindness (retinopathy), cardiac arrhythmia, heart failure and arrest, deafness (ototoxicity), seizure and coma, among others, especially when the use of these drugs occurs in higher doses and for longer periods. ${ }^{17,24}$

In addition, due to their lysosomal affinity, CQ and HCQ accumulate in cells of various tissues, including cardiac and skeletal muscles. ${ }^{17,20}$ Side effects of HCQ include irreversible effects such as cardiomyopathy, prolongation of the QT interval, proximal myopathy and neuropathy, seizures, especially in older adults, cardiovascular and epilepsy patients and patients with renal failure, all of them taking part of higher risk groups. ${ }^{12,17}$ Moreover, patients with CQ or HCQ-induced myopathy have muscle weakness, dyspnea, absence of reflexes in the legs and ventilatory failure in severe cases. It is clear, therefore, that the toxic effects of CQ and HCQ can further aggravate the health of patients with COVID19, especially the elderly, obese and diabetics, as these unwanted effects can add up or even be potentialized.

\begin{tabular}{|c|c|c|c|c|c|}
\hline Country & Sample size & Treatment & Outcome & $\mathrm{CQ} / \mathrm{HCQ}$ efficacy? & Reference \\
\hline China & $N=100$ & $\mathrm{CQ}$ & $\begin{array}{l}\text { Treated patients showed faster } \\
\text { recovery than control }\end{array}$ & Yes & 43 \\
\hline France & $N=36$ & $\begin{array}{l}\text { HCQ: } 3 \times 200 m g . \text { day }^{-1}, 10 \text { days. Part } \\
\text { of HCQ treated pacients was also } \\
\text { treated with azithromycin (AZTM). }\end{array}$ & $\begin{array}{c}\text { After } 6 \text { days, } 57.1 \% \text { CQ treated } \\
\text { patients were cured compared } \\
\text { to } 12.5 \% \text { in the control group. } \\
\text { HCQ + AZTM Group showed } \\
100 \% \text { cure. }\end{array}$ & Yes & 44 \\
\hline France & $N=80$ & $\begin{array}{l}\text { HCQ: } 3 \times 200 \mathrm{mg}^{\text {day }}{ }^{-1}, 10 \text { days. } \\
\text { AZTM: } 500 \mathrm{mg} \text { (day } 1), 250 \mathrm{mg}^{-1} \text { day }^{-1} \text {, } \\
4 \text { days. (no control group) }\end{array}$ & $\begin{array}{l}>90 \% \text { patients were cured } \\
\text { after the } 5^{\text {th }} \text { day. }\end{array}$ & Yes & 45 \\
\hline China & $N=62$ & HCQ: $2 \times 200 m$.day ${ }^{-1}, 5$ days. & $\begin{array}{l}\text { Improvement: } 80.7 \% \text { of the } \\
\text { treated group } \times 54.8 \% \text { of the } \\
\text { control group. }\end{array}$ & Parcially confirmed. & 46 \\
\hline Brazil & $N=81$ & $\begin{array}{c}\text { CQ: } 2 \text { x600mg.day }{ }^{-1}, 10 \text { days (G1); } \\
\text { 450mg.day }{ }^{-1}, 5 \text { days (G2). }\end{array}$ & $\begin{array}{l}13.5 \% \text { of death. } \mathrm{G} 1 \text { was } \\
\text { interrupted due to toxic effects } \\
\text { from } C Q \text { treatment. }\end{array}$ & No & 47 \\
\hline China & $N=30$ & HCQ: 400 mg.day ${ }^{-1}, 5$ days. & $\begin{array}{l}\text { Treated and control groups } \\
\text { achieved similar results. }\end{array}$ & No & 48 \\
\hline USA & $N=1376$ & $\begin{array}{l}\mathrm{HCQ}: 2 \times 600 \mathrm{mg} \text { (day } 1), 400 \mathrm{mg} . \\
\text { day }^{-1}, 5 \text { days. }\end{array}$ & $\begin{array}{c}\text { Treated and control groups } \\
\text { achieved similar results. }\end{array}$ & No & 49 \\
\hline France & $N=181$ & HCQ: $600 \mathrm{mg}^{\text {day }}{ }^{-1}, 7$ days. & $\begin{array}{l}\text { Treated and control groups } \\
\text { achieved similar results. }\end{array}$ & No & 50 \\
\hline France & $N=11$ & $\begin{array}{l}\text { HCQ: } 600 \mathrm{mg}^{\text {day }}{ }^{-1} 10 \text { days. } \\
\text { AZTM: } 500 \mathrm{mg} \text { (day1), } 250 \mathrm{mg} \text {. day }{ }^{-1} \text {, } \\
4 \text { days. (no control group) }\end{array}$ & $\begin{array}{l}80 \% \text { patients remained infected } \\
\text { after the } 5^{\text {th }} \text { day of treatment. }\end{array}$ & No & 51 \\
\hline China & $N=150$ & $\begin{array}{l}\text { HCQ: } 1200 \mathrm{mg}^{\text {day }}{ }^{-1} 3 \text { days; } \\
\text { 800 } \mathrm{mg}^{\text {day }} \text { day }^{-1}, 2-3 \text { weeks. }\end{array}$ & $\begin{array}{l}\text { Treatment did not improve } \\
\text { patient recovery when } \\
\text { compared to control. }\end{array}$ & No & 52 \\
\hline
\end{tabular}


At the best of knowledge, Table 2 lists all studies published so far that investigated the in vivo action of CQ/HCQ in the treatment of patients with COVID19. Three of these $e^{43-45}$ came to the conclusion that CQ and HCQ proved effective as medication and, therefore, they should be recommended in the treatment of this disease. Only one study ${ }^{46}$ concluded that the results obtained indicate a partial efficacy of these antimalarials against COVID-19 and the remaining six studies ${ }^{47-52}$ indicated that such drugs are inefficient in the clinical treatment of COVID-19, in some cases accompanied by greater toxicity and adverse effects in relation to the control group. These negative results served to justify the recommendation of not using CQ or HCQ in the treatment of COVID-19 until there are more consistent experimental data that duly support this choice.

Therefore, there is a discrepancy in results from the studies presented in Table 2. How can we understand and deal with these different results and conclusions?

The first point to be raised concerns the lack of standardization and randomization in the planning and execution of these studies. Many of them were unable to manage the experimental conditions and did not consider the numerous factors such as age ranges, gender, comorbidities, pre-infection health status and additional drug treatment received in hospitals during the administration of CQ or HCQ. Two studies carried out in France did not even use control groups over the course of the experiments, which precludes a consistent conclusion on effectiveness since there are no control data for comparison.

Another important factor to consider is the difference in the treatments performed in each study. While one study evaluates only CQ, another evaluates only HCQ and others include additional HCQ treatment with azithromycin (AZTM). In addition, there is a disparity in daily doses and treatment periods in each study, which compromises a safe comparison between studies with regard to the results achieved and conclusions drawn.

\section{Final Comments}

The present scenario remains, therefore, inconclusive. Care must be taken in the interpretations of the studies available so far. To date, the scientific community does not see any set of reliable scientific data that can convincingly support the clinical use of CQ or HCQ in the treatment of COVID-19. This understanding was also recently expressed by the World Health Organization when discontinuing the use of HCQ against COVID19. ${ }^{53}$ More controlled and better-planned studies will certainly provide results enough to corroborate (or not) this scenario definitively.

\section{ACKNOWLEDGEMENT}

The author is grateful to the Federal University of Bahia (UFBA), Brazil, for providing general support and research facilities.

\section{CONFLICT OF INTEREST}

The author declares that there is no conflict of interest.

\section{ABBREVIATIONS}

ACE-2: angiotensin-2-converting enzyme; AZTM: azithromycin; COVID-19: Corona Virus Disease of 2019; CQ: chloroquine; DNA: deoxyribonucleic acid; FDA: Food and Drug Administration; HCQ: hydroxychloroquine; MEPC: mepacrine; PAMQ: pamaquine; PRIMQ: primaquine; QN: quinine; RNA: ribonucleic acid; SARS-Cov-2: Severe Acute Respiratory Syndrome Coronavirus-2; TNF $\alpha$ : tumor necrosis factor.

\section{REFERENCES}

1. World Health Organization. Novel Coronavirus (2019-nCoV) Situation Report-1. WHO Bull. 2020;1(1):1-7.

2. Gorbalenya AE, Baker SC, Baric RS, DeGroot RJ, Drosten C, Gulyaeva AA, et al. The species severe acute respiratory syndrome-related coronavirus: classifying 2019-nCoV and naming it SARS-CoV-2. Nat Microbiol. 2020;5(4):536-44.

3. World Health Organization. Coronavirus Disease (COVID-19) Situation Report-161. WHO Bull. 2020;161(6):1-16.

4. National Institute of Allergy and Infectious Diseases. Photo of SARSCov-2. 2020. Available from: https://www.nationalgeographicbrasil.com/ photography/2020/03/fotos-de-microscopio-eletronico-mostram-particulasdo-virus-sars-cov-2?image=novel-coronavirus-sars-cov-2_49534865371_o

5. Viral Zone. Structure of SARS-Cov. 2020. Available from: https://pfarma.com. br/coronavirus/5439-origem-covid19.html

6. Qinfen Z, Jinming C, Xiaojun H, Huanying Z, Jicheng $\mathrm{H}$, Ling $\mathrm{F}$, et al. The life cycle of SARS coronavirus in Vero E6 cells. J Med Virol. 2004;73(3):332-7.

7. Pillaiyar T, Meenakshisundaram S, Manickam M. Recent discovery and development of inhibitors targeting coronaviruses. Drug Discov Today. 2020;25(4):668-88.

8. Savarino A, Boelaert JR, Cassone A, Majori G, Cauda R. Effects of chloroquine on viral infections: An old drug against today's diseases?. Lancet Infect Dis. 2003;3(11):722-7.

9. Cook G, Zumla A. Manson's tropical diseases. $22^{\text {nd }}$ ed. London: Elsevier Saunders. 2008;1238-40.

10. Parhizgar AR, Tahghighi A. Introducing new antimalarial analogues of chloroquine and amodiaquine: A narrative review. Iran J Med Sci. 2017;42(2):115-28.

11. Bruce-Chwatt L. Chemotherapy of Malaria. $2^{\text {nd }}$ ed. Geneva: WHO. 1986;9-21.

12. Adeel AA. Perspectives on repositioning chloroquine and hydroxychloroquine for the treatment of Covid-19. Sudan J Paediatr. 2020;20(1):4-9.

13. Rádl S. From chloroquine to antineoplastic drugs? The story of antibacterial quinolones. Arch Pharm. 1996;329(3):115-9.

14. Surrey AR, Hammer HF. Some 7-Substituted 4-Aminoquinoline Derivatives. J Am Chem Soc. 1946;68(1):113-6.

15. McChesney EW. Animal toxicity and pharmacokinetics of hydroxychloroquine sulfate. Am J Med. 1983;75(1 PART 1):11-8.

16. Shee JC. Lupus erythematosus treated with chloroquine. Lancet. 1953;262(6778):201-2. 
17. Schrezenmeier E, Dörner T. Mechanisms of action of hydroxychloroquine and chloroquine: Implications for rheumatology. Nat Rev Rheumatol. 2020;16(3):155-66.

18. Mallucci L. Effect of chloroquine on lysosomes and on growth of mouse hepatitis virus (MHV-3). Virology. 1966;28(3):355-62.

19. Weissmann $\mathrm{G}$. The role of lysosomes in inflammation and disease. Annu Rev Med. 1967;18(8):97-112.

20. Devaux CA, Rolain JM, Colson P, Raoult D. New insights on the antiviral effects of chloroquine against coronavirus: What to expect for COVID-19?. Int J Antimicrob Agents. 2020;55(5):105938.

21. Ferraris $\mathrm{O}$, Moroso $\mathrm{M}$, Pernet $\mathrm{O}$, Emonet $\mathrm{S}$, Rembert $\mathrm{AF}$, Paranhos-Baccalà $\mathrm{G}$, et al. Evaluation of Crimean-Congo hemorrhagic fever virus in vitro inhibition by chloroquine and chlorpromazine, two FDA approved molecules. Antiviral Res. 2015;11875-81.

22. Keyaerts E, Li S, Vijgen L, Rysman E, Verbeeck J, Ranst MV, et al. Antiviral activity of chloroquine against human coronavirus OC43 infection in newborn mice. Antimicrob Agents Chemother. 2009;53(8):3416-21.

23. Keyaerts E, Vijgen L, Maes P, Neyts J, Ranst MV. In vitro inhibition of severe acute respiratory syndrome coronavirus by chloroquine. Biochem Biophys Res Commun. 2004;323(1):264-8.

24. Liu J, Cao R, Xu M, Wang X, Zhang H, Hu H, et al. Hydroxychloroquine, a less toxic derivative of chloroquine, is effective in inhibiting SARS-CoV-2 infection in vitro. Cell Discov. 2020;6(16):1-4.

25. Dowall SD, Bosworth A, Watson R, Bewley K, Taylor I, Rayner E, et al. Chloroquine inhibited Ebola virus replication in vitro but failed to protect against infection and disease in the in vivo guinea pig model. J Gen Virol. 2015;96(12):3484-92.

26. Chandramohan M, Vivekananthan SC, Sivakumar D, Selvam P, Neyts J, Katrien G, et al. Preliminary report of anti-hepatitis $C$ virus activity of chloroquine and hydroxychloroquine in huh-5-2 cell line. Indian J Pharm Sci. 2006;68(4):538-40.

27. Li C, Zhu X, Ji X, Quanquin N, Deng YQ, Tian M, et al. Chloroquine, a FDAapproved Drug, Prevents Zika Virus Infection and its Associated Congenital Microcephaly in Mice. E Bio Medicine. 2017;24:189-94.

28. Farias KJS, Machado PRL, DeJunior RFA, DeAquino AA, Fonseca BAL. Chloroquine interferes with dengue-2 virus replication in $U 937$ cells. Microbiol Immunol. 2014;58(6):318-26.

29. Singh AK, Sidhu GS, Friedman RM, Maheshwari RK. Mechanism of enhancement of the antiviral action of interferon against herpes simplex virus-1 by chloroquine. J Interf Cytokine Res. 1996;16(9):725-31.

30. Shimizu Y, Yamamoto S, Homma M, Ishida N. Effect of chloroquine on the growth of animal viruses. Arch Gesamte Virusforsch. 1972;36(1-2):93-104.

31. Finkbeiner W. Hydroxychloroquine (HCQ) inhibits rhinovirus (RV) replication in cultured human tracheal epithelial cells. J Allergy Clin Immunol. 2004;113(2):S264.

32. Tan YW, Yam WK, Sun J, Chu JJH. An evaluation of Chloroquine as a broad-acting antiviral against Hand, Foot and Mouth Disease. Antiviral Res. 2018;149:143-9.

33. Pardridge WM, Yang J, Diagne A. Chloroquine inhibits HIV-1 replication in human peripheral blood lymphocytes. Immunol Lett. 1998;64(1):45-7.

34. Chiang G, Sassaroli M, Louie M, Chen H, Stecher VJ, Sperber K. Inhibition of HIV-1 Replication by Hydroxychloroquine: Mechanism of Action and Comparison with Zidovudine. Clin Ther. 1996;18(6):1080-92.

35. Tsiang $\mathrm{H}$, Superti F. Ammonium Chloride and Chloroquine Inhibit Rabies Virus Infection in Neuroblastoma Cells. Arch Virol. 1984;81(3-4):377-82.

36. Helenius A, Marsh M, White J. Inhibition of Semliki Forest virus penetration by lysosomotropic weak bases. J Gen Virol. 1982;58(1):47-61.
37. Khan M, Santhosh SR, Tiwari M, Rao PVL, Parida M. Assessment of in vitro Prophylactic and Therapeutic Efficacy of Chloroquine against Chikungunya Virus in Vero Cells. J Med Virol. 2010;82(5):817-24.

38. Fantini J, DiScala C, Chahinian H, Yahi N. Structural and molecular modelling studies reveal a new mechanism of action of chloroquine and hydroxychloroquine against SARS-CoV-2 infection. Int J Antimicrob Agents. 2020;55(5):105960.

39. Veskoukis AS, Kyparos A, Nikolaidis MG, Stagos D, Aligiannis N, Halabalaki M, et al. The Antioxidant Effects of a Polyphenol-Rich Grape Pomace Extract in vitro Do Not Correspond in vivo Using Exercise as an Oxidant Stimulus. Oxid Med Cell Longev. 2012;185867.

40. Mattie H. Antibiotic efficacy in vivo predicted by in vitro activity. Int J Antimicrob Agents. 2000;14(2):91-8.

41. Tsoi KM, Dai Q, Alman BA, Chan WCW. Are Quantum Dots Toxic? Exploring the Discrepancy between Cell Culture and Animal. Acc Chem Res. 2013;46(3):662-71.

42. Paton NI, Lee L, Xu Y, Ooi EE, Cheung YB, Archuleta S, et al. Chloroquine for influenza prevention: A randomised, double-blind, placebo controlled trial. Lancet Infect Dis. 2011;11(9):677-83.

43. Gao J, Tian Z, Yang X. Breakthrough: Chloroquine phosphate has shown apparent efficacy in treatment of COVID-19 associated pneumonia in clinical studies. Biosci Trends. 2020;14(1):1-2.

44. Gautret P, Lagier JC, Parola P, Hoang VT, Meddeb L, Mailhe M, et al. Hydroxychloroquine and azithromycin as a treatment of COVID-19: Results of an open-label non-randomized clinical trial. Int $\mathrm{J}$ Antimicrob Agents. 2020;105949.

45. Gautret P, Lagier JC, Parola P, Hoang VT, Meddeb L, Sevestre J, et al. Clinical and microbiological effect of a combination of hydroxychloroquine and azithromycin in 80 COVID-19 patients with at least a six-day follow up: A pilot observational study. Travel Med Infect Dis. 2020;34:101663.

46. Chen Z, Hu J, Zhang Z, Jiang S, Han S, Yan D, et al. Efficacy of hydroxychloroquine in patients with COVID-19: Results of a randomized clinical trial. Med Rxiv. 2020.

47. Borba MGS, Val FFA, Sampaio VS, Alexandre MAA, Melo GC, Brito M, et al. Effect of High vs Low Doses of Chloroquine Diphosphate as Adjunctive Therapy for Patients Hospitalized With Severe Acute Respiratory Syndrome Coronavirus 2 (SARS-CoV-2) Infection A Randomized Clinical Trial. JAMA Netw Open. 2020;3(4):e208857.

48. Chen J, Liu D, Liu L, Liu P, Xu Q, Xia L, et al. APilot Study of Hydroxychloroquine in Treatment of Patients with Moderate COVID-19. J Zhejiang Univ Med Sci. 2020;49(2):215-9.

49. Geleris J, Sun Y, Platt J, Zucker J, Baldwin M, Hripcsak G, et al. Observational Study of Hydroxychloroquine in Hospitalized Patients with Covid-19. N Engl J Med. 2020;382:2411-8.

50. Mahevas M, Tran VT, Roumier M, Chabrol A, Paule R, Guillaud C, et al. No evidence of clinical efficacy of hydroxychloroquine in patients hospitalized for COVID-19 infection with oxygen requirement: Results of a study using routinely collected data to emulate a target trial. Med Rxiv. 2020.

51. Molina JM, Delaugerre C, LeGoff J, Mela-Lima B, Ponscarme D, Goldwirt L, et al. No evidence of rapid antiviral clearance or clinical benefit with the combination of hydroxychloroquine and azithromycin in patients with severe COVID-19 infection. Med Mal Infect. 2020;50(4):384.

52. Tang W, Cao Z, Han M, Wang Z, Chen J, Sun W, et al. Hydroxychloroquine in patients mainly with mild to moderate COVID-19: An open-label, randomized, controlled trial running. Med Rxiv. 2020. 2020.04.10.20060558v2.

53. World Health Organization. WHO discontinues hydroxychloroquine and lopinavir/ritonavir treatment arms for COVID-19. News. Available from: https://www.who.int/news-room/detail/04-07-2020-who-discontinueshydroxychloroquine-and-lopinavir-ritonavir-treatment-arms-for-covid-19 


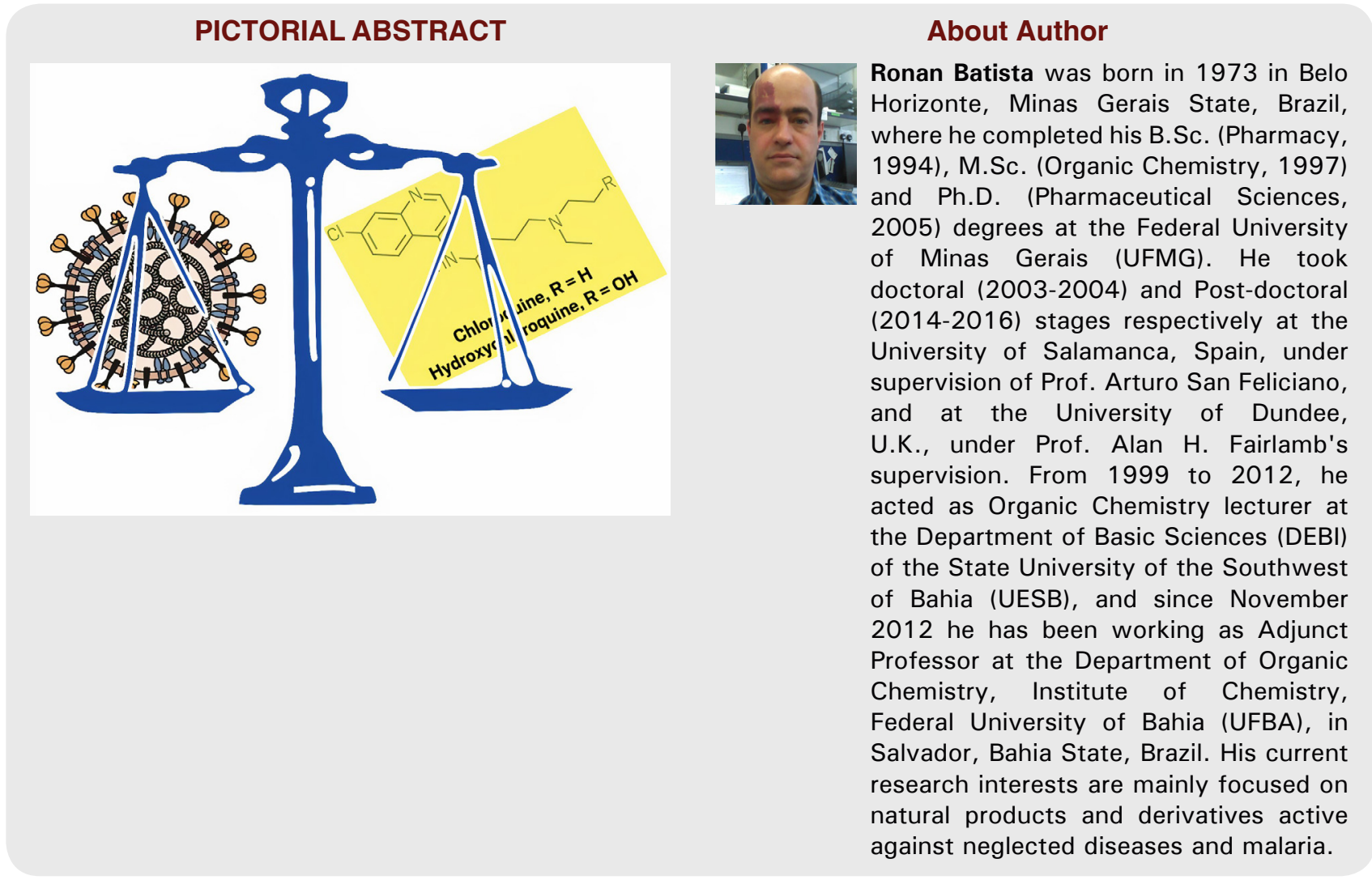

Cite this article: Batista R. Using Chloroquine and Hydroxychloroquine in the Treatment of COVID-19: Does It Make Sense?. Indian J of Pharmaceutical Education and Research. 2020;54(4):865-74. 